\title{
A Study of ICT-Based Learning in Elementary School Mathematics Learning Concepts During the COVID-19 Pandemic
}

\author{
Wiryanto Wiryanto ${ }^{1, *}$ Chusnul Chotimah ${ }^{1,}$ Ni'matur Rochmah $^{1,}$ Mario Florentino ${ }^{1}$ \\ ${ }^{1}$ Departement of Postgraduate, Universitas Negeri Surabaya, Indonesia \\ *Corresponding author. Email: wiryanto@unesa.ac.id
}

\begin{abstract}
This study aims to examine the application of technology to mathematics learning at the time of the Covid-19 pandemic. The research method used is comparative analysis research. The variables being compared are Information and communication technologies-based learning media with the contribution of several aspects, namely the total article with the title of the media, user perception, the total material that can be applied, gameplay, graphic design, and features of the application. Utilization of technology that can be used in the learning process without facing real time but has good effectiveness. The learning media are Edmodo, Geogebra, and Knowre Math. This third application helps in learning mathematics as the co-19 pandemic continues so that it does not require face-to-face but learning runs efficiently.
\end{abstract}

Keywords: Covid-19, ICT-based Learning, Mathematics education.

\section{INTRODUCTION}

Around mid-March 2020, the Indonesian government through the Minister of Health announced at a press conference that all schools, colleges, and universities will be closed indefinitely on Sunday, March 15, 2020, amid fears that the Coronavirus (COVID-19) outbreak that has been reported to have damaged most of the China, USA, Italy, Spain and other parts of the world. This means that high school students in most public and private schools end semester 1 of the 2020 academic year without taking the end-of-term exam as many public and private schools administer assessment tests at the end of each of the three academic year requirements.

There is currently little or no literature on COVID-19 in relation to educational studies. The only available literature is directly related to medical studies [1], [2]. This is not because education is not directly affected by the effects of the COVID-19 epidemic but rather because studies in education have rarely included the effects of disease on the provision of effective education for students around the world. The rapid rate of spread of COVID-19 has made every sector of human life immediately feel the impact [2].

In the education sector, there are difficulties in learning mathematics that cannot be done face-to-face. Elementary school students have a less real understanding of mathematical concepts. Because explanations in mathematical concepts require a good approach and are carried out face-to-face or meet with mathematical objects directly [3]. So that during the pandemic, several technological innovations that were not previously used became used with good utilization.

In mathematics learning, technology is widely used for materials that require images, animations, visualizations and colors [4]. Technology can be used in algebra, for example to solve systems of linear equations; in calculus, for example to draw graphs; and in arithmetic, for example to practice numeracy. In addition, there are many more mathematical materials that can be taught using technology [5].

The National Council of Supervisors states that computers are better used to develop 10 basic skills in mathematics, namely (1) problem solving, (2) applications of mathematics in everyday life, (3) opportunities, (4) estimation and approximation, (5) numeracy, (6) geometry, (7) measurement, (8) reading, interpreting and constructing tables, diagrams, and graphs, (9) use of mathematics for prediction, and (10) computer literacy.

From the general background that the aims of this research are to examine the application of ICT in mathematics learning during the Covid-19 pandemic and 
to analyze several ICT media that can be used in mathematics learning and the effectiveness of these media.

\section{LITERATURE REVIEW}

Computer programs are ideal for use in learning mathematical concepts that require high accuracy. For example, the completion of graphs is precise, fast, and accurate (Kusumah, 2003). Furthermore, Kusumah also stated that computer-assisted learning innovations are very good to be integrated with learning mathematical concepts, especially those concerning transformations of geometry, calculus, statistics, and graphs of functions.

Various uses of computers in learning mathematics are intended to support and facilitate students in understanding mathematical concepts. Thus, students' understanding of concepts should get top priority rather than just improving students' mechanistic abilities in utilizing computer programs. In this case, teacher guidance is needed to link various animations or computer program applications produced by students with relevant and underlying concepts.

In many cases, understanding concepts must precede any use of computer programs. However, within certain limits, computer programs can be utilized in the process of constructing concepts by students. Although based on its function, computer learning media can be applied at the stage of concept planting, concept understanding, and fostering concept mastery skills. The concept understanding learning stage focuses on mastering and broadening students' insight about the concepts that have been learned at the concept planting stage. Meanwhile, the learning stage of developing concept mastery skills focuses on fostering students' skills in applying the concepts that have been learned.

According to Nieveen (1999) there are several formative assessments in using learning products, namely Design specifications, Global intervention, Part of the intervention in detail, Complete intervention. With this formative assessment, the author is expected to be able to determine what learning products are best used in the current era.

\section{METHODS}

The research method used is comparative analysis research. Comparative research is comparative research, which is conducted to compare the similarities and differences of 2 or more properties and facts of the object under study based on a certain framework of thought. Comparative research is usually used to compare between 2 or more groups in a certain variable. The variables compared are ICT-based learning media by reviewing several aspects, namely the total of articles with the title of the media, user perception, total material that can be applied, gameplay, graphic design, and features in the application.

\section{RESULTS AND DISCUSSION}

\subsection{A Comparative Study of Technology Development}

Currently, Indonesia is still using face-real-time based technology. Meanwhile, it reduces the efficiency of learning, because it is known that face-to-face online is limited and we do not understand directly how students respond during learning. While there are still some uses of technology that can be used in the learning process without facing real time but have good effectiveness. The learning media are Edmodo, Geogebra, and Knowre Math.

Edmodo is one type of communication and information technology in the form of a social networking website similar to Facebook which is used for the learning process to facilitate the learning process for both educators, students, and parents that can contain various media in the form of images, animations, text, and sound. [6]. Edmodo is often referred to as the Facebook of educators because Edmodo is intended for educators, students, and parents [7].

The use of Edmodo has an important role in the learning process, namely as a medium for learning mathematics [8]. The results of research conducted by [9] state that the Edmodo learning process can create interesting, innovative, and effective learning activities. Learning. Edmodo can be accessed via the web and smartphones (Windows Phone, iOS, Android, etc.) online in which there is a virtual space for educators and students to share and discuss ideas, and files (text, images, audio, and video) [9]

One of the computer programs (software) that can be used as a medium for learning mathematics is the GeoGebra program. GeoGebra was developed by Markus Hohenwarter in 2001. GeoGebra is a computer program (software) for teaching mathematics, especially geometry and algebra [10]. According to [11], the GeoGebra program is very useful for teachers and students. Unlike the use of commercial software that can usually only be used in schools, Geogebra can be installed on personal computers and used anytime and anywhere by students. For teachers, GeoGebra offers an effective opportunity to create interactive online learning environments that allow students to explore various mathematical concepts [12].

Knowre Math is an online, aligned, standardized, grades 1 through 12 program that identifies and addresses individual student learning gaps through Knowre's Walk Me Through technology, personalized curriculum, and ongoing assessment [13]. Knowre's flexibility allows schools to use the program in a variety of ways - from 
core to supplementary, from remediation to enrichment. Knowre's vision is to provide the most effective education by systematizing world knowledge and personalizing learning experiences for students around the world [14]. By using Knowre math, it can be classified as bringing your own device-based learning. Because students use their own devices in the classroom for the learning process. There are several different approaches that can be used to investigate the use of digital devices in the classroom. Such as [15] who use augmented reality-based learning media to improve the spatial abilities of elementary school students.

Of the three educational technology products that can be used during the COVID-19 pandemic, the three technologies can be compared into several variables as shown in table 1.

Table 1. Comparison of mathematical technology development

\begin{tabular}{|c|c|c|c|}
\hline Variable & Edmodo & Algebra & $\begin{array}{c}\text { Knowre } \\
\text { Math }\end{array}$ \\
\hline $\begin{array}{l}\text { Total } \\
\text { Articles }\end{array}$ & $\begin{array}{l}\text { In google } \\
\text { scholar = } \\
1910 \\
\text { In science } \\
\text { direct = } 95\end{array}$ & $\begin{array}{l}\text { In google } \\
\text { scholar = } \\
3250 \\
\text { In } \\
\text { science } \\
\text { direct = } \\
187\end{array}$ & $\begin{array}{l}\text { In google } \\
\text { scholar }= \\
37 \\
\text { In science } \\
\text { direct }=0\end{array}$ \\
\hline $\begin{array}{l}\text { User } \\
\text { Perceptio } \\
\text { n }\end{array}$ & $87.5 \%$ & $85.71 \%$ & $79.5 \%$ \\
\hline $\begin{array}{l}\text { Materi di } \\
\text { SD }\end{array}$ & $\begin{array}{l}\text { All math } \\
\text { material in } \\
\text { elementary } \\
\text { school }\end{array}$ & $\begin{array}{l}\text { Angles, } \\
\text { Lines, } \\
\text { Flat } \\
\text { Shapes, } \\
\text { and } \\
\text { Spacing }\end{array}$ & $\begin{array}{l}\text { Algebraic } \\
\text { concepts in } \\
\text { mathematic } \\
\text { s }\end{array}$ \\
\hline Gameplay & $\begin{array}{l}\text { Answering } \\
\text { with } \\
\text { section } \\
\text { submit } \\
\text { answers or } \\
\text { available } \\
\text { question }\end{array}$ & $\begin{array}{l}\text { Answerin } \\
\text { g } \\
\text { available } \\
\text { question }\end{array}$ & $\begin{array}{l}\text { Answering } \\
\text { with section } \\
\text { submit } \\
\text { answers or } \\
\text { available } \\
\text { question }\end{array}$ \\
\hline Graphic & $2 \mathrm{D}$ & $\begin{array}{l}2 \mathrm{D} \text { and } \\
3 \mathrm{D}\end{array}$ & $2 \mathrm{D}$ \\
\hline Feature & $\begin{array}{l}\text { Assignmen } \\
\text { t, File and } \\
\text { Links, Quiz, }\end{array}$ & & $\begin{array}{l}\text { Student } \\
\text { dashboard } \\
\text { (material }\end{array}$ \\
\hline
\end{tabular}

\begin{tabular}{|l|l|l|l|}
\hline Variable & Edmodo & Algebra & $\begin{array}{l}\text { Knowre } \\
\text { Math }\end{array}$ \\
\hline & $\begin{array}{l}\text { Polling, } \\
\text { Gradebook, } \\
\text { Library, } \\
\text { Award } \\
\text { Badges, } \\
\text { Parents } \\
\text { Codes }\end{array}$ & & $\begin{array}{l}\text { map, } \\
\text { practice } \\
\text { questions } \\
\text { with videos, } \\
\text { submit } \\
\text { answers) } \\
\text { Teacher } \\
\text { Dashboard } \\
\text { (material } \\
\text { map, } \\
\text { submit } \\
\text { questions, } \\
\text { checkboard } \\
\text { the grades } \\
\text { of students } \\
\text { in one } \\
\text { class) }\end{array}$ \\
\hline
\end{tabular}

\subsection{Effectivity and Valueability of Technology}

Learning using Edmodo (online) is effective in learning mathematics because it provides a good experience, namely making it easier for students to take online quizzes that can be done from anywhere and anytime [16], easy to obtain teaching materials in sharing videos, files, folders. Mathematical communication (educators with students/students with students) during the teaching and learning process and get feedback that can help assessment [17] so that teachers can recapitulate grades automatically. Edmodo is used as a medium for teachers and students to apply more efficient, fun learning methods [18].

The effectiveness of technology can be seen through user perception of the use of Edmodo media in Table 1. It shows that $87.5 \%$ of Edmodo is effectively used by elementary school students in learning mathematics. Research results show that digital tools like Edmodo can provide students with a truly collaborative workspace outside the classroom walls, promote multiple avenues for constructive learning, and encourage higher-level thinking skills in 21st-century society [19] so that it can stimulate and equip students in mathematical communication competence in the future.

Based on the results in Table 1, students' user perception of Geogebra was $85.71 \%$ where students stated that at first students were confused with the learning given at the first meeting because students were not familiar with the learning approach applied. Then at the next meeting, the students were getting used to the applied learning, students were able to draw geometric 
shapes well through Geogebra technology so that students' understanding of spatial concepts did not occur misconceptions. Students stated that they felt more interested in participating in mathematics learning because it was more interesting, especially when they were getting bored in learning, learning games were inserted to train their concentration.

The effectiveness of technology can be seen in Table 1 which shows that $79.5 \%$ of students' user perception of the Knowre Math learning media gives responses that students enter in WMT fulfill three main functions. First, they allow programs to check to understand and determine what skills or topics are causing problems the way a teacher would. The data obtained in the examination is transferred to the teacher in real time. Second, they provide opportunities for students to overcome prior knowledge gaps by practicing the required skills. Finally, the active involvement of students in WMT makes them involved in the learning process.

\subsection{Discussion}

From the results of a comparative study, it can be seen that using interactive technology has its advantages and disadvantages. The comparison in this study is expected to help teachers to use technology as well as possible during this covid-19 pandemic. Because not meeting face to face does not mean being a barrier in the provision of knowledge. The results of this study all point to the fact that COVID-19 will have an adverse effect on the education sector in Indonesia. The reasons for this expected technological development are largely due to the loss of contact hours for high school students and the lack of e-learning facilities that students can use to interact with their teachers.

The results also seem to indicate that teachers are increasing their readiness to contain the negative effects of this epidemic by bringing in pedagogical strategies aimed at ensuring that students in exam classes are adequately prepared for exams. It is also a common feeling that the implementation of the STEM curriculum in the schools selected to pilot its rollout will have dire consequences as the curriculum is expensive to implement and the state of the national economy after COVID-19 will not have the muscle to fully support these schools. It is also hoped that donor funding to support STEM implementation can be reduced because donor countries are also not spared from the COVID-19 pandemic [20].

Information and Communication Technology (ICT) is currently a tool that plays an important role in the world of education, especially in learning mathematics. In general, the role or function of technology in mathematics education can be categorized into three different functions [21]. First, technology serves as a tool for doing mathematical calculations. Second, technology serves as a place of learning to practice mastery of mathematical skills. And third, technology serves as a tool that can be used for concept development and understanding.

In the function of technology as a tool for doing mathematics, users Technology does not need to know and also does not need to understand how technology solves the mathematical problems encountered [22]. In other words, the process of obtaining results does not need to be visible to the user's eyes. In this case, technology only serves to help streamline troubleshooting time. In its function as a tool to practice mastery of mathematical skills, technology plays a role in honing and strengthening user skills in carrying out problem-solving procedures. For this second function, technology is usually used to solve routine problems. In its function as a tool for concept development and understanding, technology serves to assist students in understanding a concept through, for example, a guided inquiry process.

\section{CONCLUSION}

In this study, we conducted a comparative study of 3 technologies as a medium for learning mathematics in the COVID-19 pandemic, namely Edmodo, Geogebra, and Knowre Math. The variables compared are ICT-based learning media by reviewing several aspects, namely the total of articles with the title of the media, user perception, total material that can be applied, gameplay, graphic design, and features in the application. The three applications help in learning mathematics during the covid-19 pandemic so that it does not require face-to-face but learning runs efficiently.

From this research, it is hoped that it can help teachers who cannot carry out face-to-face learning so that they can use application options in this learning to help students understand mathematical concepts.

\section{REFERENCES}

[1] M. Chinazzi et al., "The effect of travel restrictions on the spread of the 2019 novel coronavirus (COVID-19) outbreak," Science (80-. )., vol. 368, no. 6489, pp. 395-400, 2020, doi: https://doi.org/10.1126/science.aba9757.

[2] M. U. Kraemer et al., "The effect of human mobility and control measures on the COVID-19 epidemic in China," Science (80-. )., vol. 368, no. 6490, pp. 493-497, 2020, doi: https://doi.org/10.1126/science.abb4218.

[3] M. Mukwambo, K. Ngcoza, and L. F. Ramasike, "Use of Angle Model to Understand Addition and Subtraction of Fractions," Pedagog. Res., vol. 3, no. 1, pp. 1-8, 2018, doi: 10.20897/pr/85174. 
[4] A. Deshpande and I. Kim, "The effects of augmented reality on improving spatial problem solving for object assembly," Adv. Eng. Informatics, vol. 38, no. March, pp. 760-775, 2018, doi: 10.1016/j.aei.2018.10.004

[5] N. A. A. González, "How to Include Augmented Reality in Descriptive Geometry Teaching," Procedia Comput. Sci., vol. 75, no. Vare, pp. 250256, 2015.

[6] F. Gruber, "Edmodo: Microblogging for Education," Some What Frank, 2008. http://www.somewhatfrank.com/2008/03/Edmodomicroblo.html (accessed May 02, 2020).

[7] A. Nasrullah and S. Ende, "Efektivitas Penggunaan Media Edmodo Pada Pembelajaran Matematika Ekonomi Terhadap Komunikasi Matematis," $J$. Res. Math. Learn. Educ., vol. 2, no. 1, pp. 25482297, 2017.

[8] F. Imam, "Efektifitas E-learning Melalui Edmodo terhadap Hasil Belajar Peserta Didik pada Materi Statistika SMA," Universitad PGRI Semarang, 2013.

[9] K. M. Al-said, "Student's Perceptions of Edmodo and Mobile Learning and their Real Barriers towards them," Turkish online J. Educ. Technol., vol. 14, no. 2, pp. 167-180, 2015.

[10] M. Khalil, U. Khalil, and Z. ul Haq, "Geogebra as a Scaffolding Tool for Exploring Analytic Geometry Structure and Developing Mathematical Thinking of Diverse Achievers," Int. Electron. J. Math. Educ., vol. 14, no. 2, pp. 427-434, 2019, doi: 10.29333/iejme/5746.

[11] P. Fitriasari, "Pemanfaatan Software Geogebra Dalam Pembelajaran Matematika," J. Pendidik. Mat. RAFA, vol. 3, no. 1, pp. 57-69, 2017, doi: 10.19109/jpmrafa.v3i1.1441.

[12] Lainufar, Mailizar, and R. Johar, "A need analysis for the development of augmented reality basedgeometry teaching instruments in junior high schools," J. Phys. Conf. Ser., vol. 1460, no. 1, 2020, doi: 10.1088/1742-6596/1460/1/012034.

[13] F. G. Karaoglan Yilmaz, B. G. Özdemir, and Z. Yasar, "Using digital stories to reduce misconceptions and mistakes about fractions: an action study," Int. J. Math. Educ. Sci. Technol., vol. 49, no. 6, pp. 867-898, 2018, doi: 10.1080/0020739X.2017.1418919.

[14] H. E. Rudyanto, Marsigit, M. N. Wangid, and S. Gembong, "The use of bring your own device-based learning to measure student algebraic thinking ability," Int. J. Emerg. Technol. Learn., vol. 14, no. 23, pp. 233-241, 2019, doi: 10.3991/ijet.v14i23.11050.

[15] M. F. Amir, C. Chotimah, R. Afandi, H. E.
Rudyanto, and I. Anshori, "Design Research Study : Investigation of Increasing Elementary Student' s Spatial Ability Using 3Dmetric," J. Adv. Res. Dyn. Control Syst., vol. 10, no. 6, pp. 1707-1713, 2018.

[16] C. Kongchan, "How a Non-Digital Native Teacher Makes Use of Edmodo," 2012.

[17] E. Dogoriti and J. Pange, "Instructional Design for a 'Social' Classroom: Edmodo and Twitter in the Foreign Language Classroom," in International Conference on Information Communication Technologies in Education, 2014, pp. 154-165.

[18] Y. Zakaria and M. Irfan, "peningkatan proses belajar siswa melalui model pembelajaran sea digital class menggunakan edmodo dan webex," STMIK IKMI Cirebon, 2017.

[19] C. Mcclain, "Characterization Personified: Using Edmodo to Strengthen Student Interaction with Literature Alan Brown," Sch. Comput. Technol. J., vol. 18, pp. 1-9, 2015.

[20] R. Al-Azawi, A. Albadi, R. Moghaddas, and J. Westlake, "Exploring the Potential of Using Augmented Reality and Virtual Reality for STEM Education," in Learning Technology for Education Challenges, vol. 1011, no. 1, L. Uden, D. Liberona, G. Sanchez, and S. Rodríguez-González, Eds. Switzerland: Springer International Publishing, 2019, pp. 36-44.

[21] B. Piper, S. Simmons Zuilkowski, M. Dubeck, E. Jepkemei, and S. J. King, "Identifying the essential ingredients to literacy and numeracy improvement: Teacher professional development and coaching, student textbooks, and structured teachers' guides," World Dev., vol. 106, p. 324, 2018, doi: 10.1016/j.worlddev.2018.01.018.

[22] G. Mihladiz and M. Duran, "Views of Elementary Education Students Related to Science and Technology Teaching Process," Procedia - Soc. Behav. Sci., vol. 141, pp. 290-297, 2014, doi: 10.1016/j.sbspro.2014.05.051. 